\title{
Determination of the quality parameters of African catfish (Clarias gariepinus) finger during refrigerated storage
}

\section{Soğukta depolanan karabalık kroketlerinin kalite parametrelerinin tespiti}

\author{
Beyza Ersoy Altun* (i) - Figen Kaba Güngör \\ Faculty of Marine Sciences and Technology, İskenderun Technical University, Hatay, Turkey \\ * Corresponding author: beyza.altun@iste.edu.tr
}

How to cite this paper:

Ersoy Altun, B \& Kaba Güngör F. (2017). Determination of the quality parameters of African catfish (Clarias gariepinus) finger during refrigerated storage. Ege Journal of Fisheries and Aquatic Sciences, 34(4):369-373. doi: 10.12714/egejfas.2017.34.4.02

\begin{abstract}
The quality parameters and shelf life of African Catfish (Clarias gariepinus) fingers during the storage at $+4^{\circ} \mathrm{C}$ were investigated in terms of sensory, chemical and microbiological changes. Sensory, chemical [pH, total volatile basic nitrogen (TVB-N)] and microbiological (total aerobic mesophylic bacteria (TAMB), total yeast and mold, coliform bacteria and salmonella) analyses were performed during the storage. $\mathrm{pH}$ values decreased significantly ( $<<0.05)$; on the other hand TVB-N value increased statistically. These values were lower than the acceptable limits at the end of the 21-days of storage. Sensory scores declined to lower than acceptable limit of consumption after $12^{\text {th }}$ day of the storage. Microbiological values were lower than maximum limits during the 12-days of storage of fish finger. TAMB level exceeded $7 \mathrm{log}$ cfu/g after 12 days. At the end of the storage period, pH, TVB-N, TAMB, total yeast and mould were determined as $5.88,31.75$ $\mathrm{mg} \mathrm{N} / 100,8.18 \mathrm{log}$ cfu/g and $5.87 \mathrm{log}$ cfu/g, respectively. It was also concluded that African catfish is a good source for producing fish finger and its products could be stored in a refrigerator $\left(a t+4^{\circ} \mathrm{C}\right)$ for at least 12 days.
\end{abstract}

Keywords: Clarias gariepinus, fish finger, chilled storage, quality parameters

Öz: $+4^{\circ} \mathrm{C}$ 'de depolama boyunca karabalık kroketlerinin (Clarias gariepinus) kalite parametreleri ve raf ömrü duyusal, kimyasal ve mikrobiyolojik değişiklikler bakımından araştııımıștır. Depolama süresince duyusal, kimyasal [pH, toplam uçucu bazik nitrojen (TVB-N)] ve mikrobiyolojik (toplam aerobik mezofilik bakteri, toplam maya-küf, koliform bakteri ve salmonella) analizleri gerçekleştirilmiştir. TVB-N değeri istatistiki olarak önemli ölçüde $(\mathrm{p}<0.05)$ artmasına rağmen, $\mathrm{pH}$ değeri azalmışıı. Bu değerler 21 günün sonunda kabul edilebilir limitlerin altında kalmıştır. Duyusal skorlar 12 gün sonra tüketilebilirlik limitinin altında tespit edilmiştir. Mikrobiyolojik değerler 12 günlük depolama boyunca kabul edilebilir değerlerden daha düşük bulunmuştur. TAMB seviyesi 12 günden sonra 7 log kob/g'। aşmıştır. Depolama periyodu boyunca pH, TVB-N, TAMB, toplam maya ve küf değerleri sırasıly $5.88,31.75 \mathrm{mg} \mathrm{N} / 100,8.18 \mathrm{log}$ kob/g ve 5.87 log kob/g olarak tespit edilmiştir. Karabalı̆ın balık kroket üretimi iç̧in iyi bir kaynak olduğu ve bu ürünlerin buzdolabında en az 12 gün depolanabileceği $\left(+4^{\circ} \mathrm{C}\right)$ tespit edilmiştir.

Anahtar kelimeler: Clarias gariepinus, balık kroket, soğuk depolama, kalite parametreleri

\section{INTRODUCTION}

African catfish (Clarias gariepinus), which has a wide distribution from the South and Central Africa to the Middle East and Turkey, is a common commercial species in the southern region of Turkey, especially in Hatay province. 486 tons of African catfish were caught in 2007 (Anonymous, 2007) which were consumed locally. Hence, African catfish is an important source of cheap and high-quality protein for the region.

In recent years, the increase of world population, socioeconomic factors and increase of numbers of working women have led to consumer's preference to ready-to-eat foods. Fish finger is one of ready-to-eat foods. Fish fingers, known as fish sticks are processed food made using a whitefish such as cod, haddock or pollock which have been battered or breaded. They are commonly available in the frozen food section of supermarkets and on children's menus in family- oriented restaurants. They can be baked in the oven, grilled, shallow fried, or deep-fried (FAO/WHO, 1989). Some reports have focused on quality changes of fish fingers during processing and frozen storage (Çakli et al., 2005; Gökoğlu and Yerlikaya, 2009; Elyasi et al., 2010; Berik et al., 2011; İzci et al., 2011). Ersoy and Yılmaz (2003) investigated frozen storage of fish balls from African catfish as the storage of an alternative product. Ersoy (2000) also studied refrigerator shelf life conditions of African catfish balls. However, there are no studies on fish fingers produced from African catfish mince.

The aim of this study was to produce fish fingers from African catfish, because of their suitability in producing fish fingers, and to investigate the sensory, chemical and microbiological quality changes of the fish fingers during refrigerated storage. 


\section{MATERIALS AND METHODS}

Sample preparation

African catfish C. gariepinus captured from Lake Gölbaşı in Turkey was used for this study. A total $10 \mathrm{~kg}$ fish comprised of 31 individuals, $120 \pm 2.25 \mathrm{~g}$ in weight and $4.47 \pm 1.14 \mathrm{~cm}$ in length, was transported to laboratory in ice boxes following the capture.

Fish were gutted, washed with tap water, skinned, filleted and cut into pieces. Flesh yield was $40 \%$ and $4 \mathrm{~kg}$. Obtained flesh was minced at room temperature with a Blue House BH560MG (1600 W) grinder using a $3 \mathrm{~mm}$ diameter holes plate.

Fish fingers were produced as 25 gr products. Each included $73 \%$ fish mince, $12 \%$ potato, $6 \%$ milk, $0.5 \%$ bread, $1.2 \%$ semolina, $0.24 \%$ cumin, $0.24 \%$ coriander, $0.48 \%$ salt, $6 \%$ wheat flour. The ingredients were homogenized with blender for 3 minutes and shaped into fish fingers. A total of 220 catfish fingers were produced and covered with conventional breading crumbs before pre-frying in 1 It sun flower oil at $180^{\circ} \mathrm{C}$ for $60 \mathrm{~s}$. Fish fingers were cooled at room temperature. Four catfish fingers $(75 \times 50 \mathrm{~mm})$ were packaged in a foam plate $(21 \times 12 \times 3$ $\mathrm{cm}$ in size) and wrapped with cling film. They were stored at $+4^{\circ} \mathrm{C} \pm 1$ for 21 days.

The initial sensory quality as well as chemical and microbiological quality of catfish fingers were performed at day 0 . All of the analyses were performed in triplicates in an air conditioned laboratory at $18^{\circ} \mathrm{C}$.

\section{Sensory analysis}

Sensory quality of fish fingers produced from mince was assessed by six trained persons. Fish fingers were deep-fried with sunflower oil until they were cooked and then they were served to the panelists to evaluate the sensory attributes of the samples. Sensory evaluation was carried out according to Kurtcan and Gönül (1987). Panelists scored for appearance, colour, odour, texture, flavour and general acceptability, using a five-point. The overall quality evaluation criteria as follows: 5 very good, 4 good, 3 medium, 2 acceptable limit of consumption, 1 below consumption limits.

\section{Chemical analysis}

$\mathrm{pH}$ value was measured as described by Lima Dos Santos et al. (1981), by using a digital pH meter (Orion 420 A). Total volatile basic nitrogen (TVB-N, mg N/100 g) values were determined, as described by Botta et al. (1984).

\section{Microbiological analysis}

For all microbiological counts, $10 \mathrm{~g}$ of sample was taken and transferred into $90 \mathrm{ml}$ peptone water $(0.1 \%$ peptone, Oxoid $L 37$ ) and homogenized for 3 minutes. Further decimal serial dilutions were prepared from this homogenate. TAMB count was determined by using the pour plate method. Plate Count Agar (PCA, Oxoid) was used as medium. Plates were incubated at $37{ }^{\circ} \mathrm{C}$ for $48 \mathrm{~h}$ (Harrigan, 1998). Potato Dextrose Agar was used as the medium for total mould-yeast counts. Plates were incubated at $21^{\circ} \mathrm{C}$ for $120 \mathrm{~h}$ (Oxoid, 1982). Violet Red Bile Agar (Difco B12) was used for the coliform bacteria count. The samples were incubated at $30^{\circ} \mathrm{C}$ for $24 \mathrm{~h}$ and the red precipitation zones that occured during incubation were counted (ICMSF, 1982). For salmonella sp., samples were taken and transferred into peptone water and homogenized. Then samples were incubated at $37^{\circ} \mathrm{C}$ for $24 \mathrm{~h}$ in Triple Sugar Iron Agar (TSIA) (Oxoid, CM 277) and Lysine Iron Agar (LIA) (Oxoid, CM 381) medium. The typical colonies were evaluated (ICMSF, 1982).

\section{Statistical analysis}

Analysis of variance was used to evaluate the analysis data and significant differences among means were determined by One-way analysis of variance (ANOVA) and Duncan's Multiple Range Test $(p=0.05)$ (SPSS 16.0 for windows). Duncans multiple range test for chemical quality and the Kruskal-Wallis for sensory quality were used to find significant differences between storage periods.

\section{RESULTS}

Table 1 shows total aerobic mesophylic bacteria (TAMB), salmonella, coliform bacteria, total yeast and mould counts of fish fingers during refrigerated storage.

Table 1. Microbial changes of fish finger during storage at $4^{\circ} \mathrm{C}$

\begin{tabular}{lllll}
\hline $\begin{array}{l}\text { Storage Period } \\
\text { (Day) }\end{array}$ & TAMB & Salmonella & $\begin{array}{l}\text { Coliform } \\
\text { bacteria }\end{array}$ & Total yeast and mould \\
\hline $\mathbf{0}$ & $3.87 \pm 0.06^{\mathrm{a}}$ & $\mathrm{Nd}$ & $\mathrm{Nd}$ & $1.63 \pm 0.05^{\mathrm{a}}$ \\
$\mathbf{3}$ & $4.03 \pm 0.02^{\mathrm{ab}}$ & $\mathrm{Nd}$ & $\mathrm{Nd}$ & $1.81 \pm 0.08^{\mathrm{a}}$ \\
$\mathbf{6}$ & $4.27 \pm 0.06^{\mathrm{b}}$ & $\mathrm{Nd}$ & $\mathrm{Nd}$ & $2.22 \pm 0.04^{\mathrm{b}}$ \\
$\mathbf{9}$ & $5.36 \pm 0.09^{\mathrm{c}}$ & $\mathrm{Nd}$ & $\mathrm{Nd}$ & $2.53 \pm 0.05^{\mathrm{b}}$ \\
$\mathbf{1 2}$ & $6.09 \pm 0.04^{\mathrm{d}}$ & $\mathrm{Nd}$ & $\mathrm{Nd}$ & $3.36 \pm 0.09^{\mathrm{c}}$ \\
15 & $7.19 \pm 0.06^{\mathrm{e}}$ & $\mathrm{Nd}$ & $\mathrm{Nd}$ & $4.15 \pm 0.09^{\mathrm{d}}$ \\
18 & $7.83 \pm 0.03^{\mathrm{f}}$ & $\mathrm{Nd}$ & $\mathrm{Nd}$ & $5.08 \pm 0.06^{\mathrm{e}}$ \\
$\mathbf{2 1}$ & $8.18 \pm 0.04^{\mathrm{a}}$ & $\mathrm{Nd}$ & $\mathrm{Nd}$ & $5.87 \pm 0.06^{f}$ \\
\hline
\end{tabular}


At day 0 TAMB count and, total yeast-mould counts of fish fingers were determined as $3.87 \mathrm{log} \mathrm{cfu} / \mathrm{g}$ and $1.63 \mathrm{log} \mathrm{cfu} / \mathrm{g}$ respectively. However, total coliform bacteria and salmonella were not detected (Table 1).

TAMB of the fish fingers stayed around 3.87-6.09 log cfu/g at the end of the 12 days of cold storage. These values were found to be $8.18 \mathrm{log}$ cfu/g at the end of the storage.

Total yeast and mold significantly $(P<0.05)$ increased during storage.
Yeast and mold was found to be $3.36 \log$ cfu/g on $12^{\text {th }}$ day of the storage.

The $\mathrm{pH}$ value of fish finger was found to be 6.80 at day 0 (Table 2). After storage period, the $\mathrm{pH}$ value of fish finger was significantly $(p<0.05)$ decreased and this value was found to be 5.88 at the end of the $12^{\text {th }}$ day of the storage. The TVB-N value of catfish fingers was measured as $6.06 \mathrm{mg} / 100 \mathrm{~g}$ at the beginning of the storage. Significant $(P<0.05)$ increase was observed in TVB-N values during storage period (Table 2).

Table 2. $\mathrm{pH}$ and TVB-N values of fish finger during storage at $4^{\circ} \mathrm{C}(\mathrm{mg} \mathrm{N} / 100)$

\begin{tabular}{cll}
\hline Storage Period (Day) & $\mathrm{pH}$ & TVB-N (mg N/100) \\
\hline $\mathbf{0}$ & $6.80 \pm 0.00^{\mathrm{a}}$ & $6.06 \pm 0.01^{\mathrm{e}}$ \\
$\mathbf{2}$ & $6.78 \pm 0.00^{\mathrm{a}}$ & $10.21 \pm 0.00^{\mathrm{de}}$ \\
$\mathbf{5}$ & $6.74 \pm 0.01^{\mathrm{a}}$ & $12.05 \pm 0.01^{\mathrm{cde}}$ \\
$\mathbf{7}$ & $6.69 \pm 0.01^{\mathrm{a}}$ & $17.60 \pm 0.11^{\mathrm{bcd}}$ \\
$\mathbf{9}$ & $6.40 \pm 0.00^{\mathrm{b}}$ & $20.49 \pm 0.11^{\mathrm{bc}}$ \\
$\mathbf{1 2}$ & $6.36 \pm 0.01^{\mathrm{bc}}$ & $23.05 \pm 0.00^{\mathrm{ab}}$ \\
14 & $6.28 \pm 0.00^{\mathrm{bc}}$ & $23.17 \pm 0.06^{\mathrm{ab}}$ \\
16 & $6.22 \pm 0.01^{\mathrm{c}}$ & $25.99 \pm 0.00^{\mathrm{ab}}$ \\
19 & $5.98 \pm 0.01^{\mathrm{d}}$ & $27.24 \pm 0.01^{\mathrm{ab}}$ \\
$\mathbf{2 1}$ & $5.88 \pm 0.01^{\mathrm{d}}$ & $31.75 \pm 0.11^{\mathrm{a}}$
\end{tabular}

aValues are shown as mean \pm standard deviation of triplicates, $n=3$

${ }^{b}$ within the column values with different letters are significantly different $(P<0.05)$

Sensory changes and overall acceptability of fish fingers produced from catfish are given in Table 3 . According to the results of overall sensory evaluation of fish fingers significantly declined after the 12 days of cold storage priod. $(p<0.05)$.

Table 3. Sensory changes of fish finger during storage at $4^{\circ} \mathrm{C}$

\begin{tabular}{|c|c|c|c|c|c|c|}
\hline Days & Apparance & Colour & Odour & Texture & Flavour & General Acceptability \\
\hline 0 & $4.8 \pm 0.2^{a}$ & $4.8 \pm 0.2^{a}$ & $4.7 \pm 0.2^{a}$ & $4.7 \pm 0.2^{a}$ & $4.8 \pm 0.2^{a}$ & $4.7 \pm 0.2^{a}$ \\
\hline 2 & $4.7 \pm 0.2^{a}$ & $4.5 \pm 0.2^{\mathrm{ab}}$ & $4.3 \pm 0.2^{\mathrm{ab}}$ & $4.3 \pm 0.2^{\mathrm{ab}}$ & $4.2 \pm 0.2^{\mathrm{ab}}$ & $4.3 \pm 0.2^{\mathrm{ab}}$ \\
\hline 5 & $4.2 \pm 0.3^{a b}$ & $4.0 \pm 0.3^{b}$ & $3.8 \pm 0.2^{b c}$ & $3.7 \pm 0.2^{\mathrm{bc}}$ & $3.8 \pm 0.3^{b}$ & $3.8 \pm 0.3^{b}$ \\
\hline 7 & $3.8 \pm 0.2^{b c}$ & $3.8 \pm 0.4^{b}$ & $3.7 \pm 0.2^{c}$ & $3.3 \pm 0.2^{c}$ & $3.5 \pm 0.2^{b}$ & $3.7 \pm 0.2^{b}$ \\
\hline 9 & $3.3 \pm 0.2^{c}$ & $2.8 \pm 0.3^{c}$ & $3.3 \pm 0.2^{c}$ & $3.2 \pm 0.3^{c}$ & $2.7 \pm 0.2^{c}$ & $2.8 \pm 0.2^{c}$ \\
\hline 12 & $1.8 \pm 0.3^{d}$ & $2.3 \pm 0.2^{\mathrm{cd}}$ & $2.0 \pm 0.2^{d}$ & $2.0 \pm 0.3^{d}$ & $1.8 \pm 0.3^{d}$ & $2.0 \pm 0.4^{d}$ \\
\hline 14 & $1.3 \pm 0.2^{\mathrm{de}}$ & $1.7 \pm 0.2 \mathrm{de}$ & $1.5 \pm 0.2^{d}$ & - & - & $1.2 \pm 0.2^{\mathrm{e}}$ \\
\hline 16 & $1.0 \pm 0.0 \mathrm{e}$ & $1.0 \pm 0.2^{e}$ & $1.0 \pm 0.0^{e}$ & - & - & $1.0 \pm 0.0^{e}$ \\
\hline 19 & $1.0 \pm 0.2^{\mathrm{e}}$ & $1.0 \pm 0.0^{\mathrm{e}}$ & $1.0 \pm 0.0^{e}$ & - & - & $1.0 \pm 0.0^{e}$ \\
\hline 21 & $1.0 \pm 0.0 \mathrm{e}$ & $1.0 \pm 0.0^{e}$ & $1.0 \pm 0.0^{e}$ & 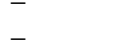 & - & $1.0 \pm 0.0^{\mathrm{e}}$ \\
\hline
\end{tabular}

aValues are shown as mean \pm standard deviation of triplicates, $n=6$

${ }^{b}$ within the column values with different letters are significantly different $(P<0.05)$

\section{DISCUSSION}

TAMB and salmonella were not detected. It was reported by other authors (Sowmya Praneetha et al., 2015) that pathogenic bacteria like Salmonella and Escherichia coli were not detected in fish finger during the entire period of refrigerated temperature. Absence of other pathogenic bacteria like Salmonella and Escherichia coli might be due to flash frying of the product. Total aerobic mesophylic bacteria level did not exceed the maximum limits (7 log cfu/g) of microbiological criteria for fresh fish given by the International Commission on Microbiological Specifications for Foods. The maximum log cfu for breaded and precooked fish products (fish sticks, fish cakes) was given as 7 log cfu/g (ICMSF, 1978). In this study the TAMB counts of the fish fingers were lower than the maximum limit until $12^{\text {th }}$ day. Similar to our results, Patır et al. (2009) found that the numbers of total aerobic mesophilic bacteria were $5.04 \mathrm{log}$ $\mathrm{cfu} / \mathrm{g}$ on the day zero. The number increased rapidly in shrimp 
fingers stored at $4 \circ \mathrm{C}$ and reached to $6.50 \mathrm{log}$ cfu/g on the $3^{\text {rd }}$ day. The number of mould and yeast of shrimp finger stored at the $4^{\circ} \mathrm{C}$ increased from $1.73 \mathrm{log}$ cfu/g to $2.22 \mathrm{log} \mathrm{cfu} / \mathrm{g}$ at the end of 3 days. The same increase of bacterial count was observed by various researchers in different fish products stored in refrigerated condition (Taskaya et al., 2003; Kılınç, 2007; Baygar et al., 2008). Similar to our results, TAMB and Psychrophilic bacteria level did not exceed the maximum level of $7 \mathrm{log}$. cfu/g of meat as described by the ICMSF (1978).

This increase is thought due to spices and additives used in making fish finger. This conclusion implies that sensory analysis correlated with the microbiological analysis of the samples.

The $\mathrm{pH}$ value does not offer a certain criterion of spoilage. It has to be supported by other chemical, sensory and microbiological analysis. The $\mathrm{pH}$ value of fresh fish is often between 6.0-6.5 (Schormüller, 1968; Ludorf and Meyer, 1973 Varlık et al., 1993). In accordance with the findings of our investigations, Inanlı et al. (2005) have reported a pH value decreasing from 6.85 to 5.69 for 21 days cold storage of Barbus esocinus. Praneetha et al. (2015) reported that the $\mathrm{pH}$ value of fish fingers from Rohu (Labeo rohita) decreased significantly $(P<0.01)$ from 6.95 to 6.44 for 15 days refrigerated storage.

The TVB-N is used for the determination of the spoilage level and fish quality during the storage period (Kietzmann et al., 1969; Cobb and Vender-Zont, 1975; Oehlenschlager, 1981). The TVB-N value is affected by species, catching season and region, age and sex of fish. A level of $35 \mathrm{mg} / 100 \mathrm{~g}$ has been considered as the maximum limit, above which fishery products are considered as unfit for human consumption (Schormüller, 1968; Ludorf and Meyer, 1973). As expected, a significant $(p<0.05)$ increase was observed in TVB-N values at the end of the cold storage (Table 2). Similarly, Inanlı et al. (2005) reported that the initial TVB-N value of fish fingers made from Barbus esocinus was $6.56 \mathrm{mg} / 100 \mathrm{~g}$, and this value increased to $28.16 \mathrm{mg} / 100 \mathrm{~g}$ at the end of the cold storage. Patır et al. (2009) reported that the TVB-N values of shrimp

\section{REFERENCES}

Anonymous (2007). Fisheries Statistics. State Institute of Statistics. Ankara: Prime Ministry Republic of Turkey.

Baygar, T., Erkan, N., Mol, S., Ozden, O., Ucok, D. \& Yildirim, Y. (2008) Determination of the shelf-life of trout (Oncorhynchus mykiss) raw meat ball that packed under modified atmosphere. Pakistan Journal of Nutrition, 7(3):412-417. doi: 10.3923/pjn.2008.412.417

Berik, N., Çankırıııil, C. \& Kahraman, D. (2011). Alabalık (Oncorhynchus mykiss) Filetosundan Kroket Yapımı ve Kalite Niteliklerinin Belirlenmesi. Kafkas Üniversitesi Veterinerlik Fakültesi Dergisi, 17(5):735-740. doi: $10.9775 / k v f d .2011 .4313$

Botta, J.R., Lauder, J.T. \& Jewer, M.A. (1984). Effect of methodology on total volatile basic nitrogen (TVBN) determination as an index of quality of fresh Atlantic cod (Gadus morhua). Journal of Food Science, 49:34-736. doi: 10.1111/j.1365-2621.1984.tb13197.x

Cobb, B.F. \& Venderzont, G. (1975). Development of a chemical test for shrimp quality. Journal of Food Science, 40:121-124. doi: 10.1111/j.1365-2621.1975.tb03751.x finger stored at the $4^{\circ} \mathrm{C}$ during 3 days, increased from 4.20 to $16.10 \mathrm{mg} / 100 \mathrm{~g}$ at the end of 3 days of storage. Praneetha et al. (2015) reported that The TVBN content of fish fingers made from Rohu (Labeo rohita) steadily increased significantly $(P<0.01)$ from an initial value of 2.65 to $4.43 \mathrm{mg} / 100 \mathrm{~g}$ sample during 15 days refrigerated storage. It was reported that the sensory scores of fish fingers obtained from Sarda sarda decreased in all groups by increasing duration of storage (Emir Çoban, 2013).

Similarly to our finding, a significant increase $(p<0.05)$ in TVB-N values $(31.75 \mathrm{mg} / 100 \mathrm{~g}$ ) was observed at the end of the storage. However, the TVB-N values of catfish fingers have remained between consumption limits during storage.

Evaluation of overall sensory acceptability revealed that catfish fingers were in consumable limits at twelfth day of storage. Similarly, İnanlı et al. (2005) was reported that the sensory properties of fish fingers of Barbus esocinus stored at $+4{ }^{\circ} \mathrm{C}$ determined as "bad" quality in day 12 ; hence, they reported that the shelf life was determined as 12 day at cold storage. These results indicated that fish fingers could be stored at $+4^{\circ} \mathrm{C}$ for 12 days while retaining their good quality characteristics in terms of sensory assessment.

These conclusions were supported by the results for chemical and microbiological quality analyses.

Based on all this information, African catfish (Clarias gariepinus) was found suitable for fish finger production as an alternative product and the product could be stored for 12 days at $4^{\circ} \mathrm{C}$. The refrigerated storage $\left(+4^{\circ} \mathrm{C}\right)$ process had a significant effect on the sensory properties, physical, chemical and microbiological quality of fish finger. Therefore, we believe that the results have high practical importance in the field of refrigerated storage of the fish products.

\section{ACKNOWLEDGEMENTS}

This research was supported by the research fund of the University of Mustafa Kemal.

Çakli, S., Taşkaya, L., Kisla, D., Çelik, U., Ataman, C.A., Cadun, A., Kılınç, B. \& Maleki, R.H. (2005). Production and quality of fish finger from different fish species. European Food Research and Technology, 220:526-530. doi: 10.1007/s00217-004-1089-9

Elyasi, A., Zakipour, Rahim Abadi, E., Sahari, M.A. \& Zare, P. (2010). Chemical and microbial changes of fish fingers made from mince and surimi of common Carp (Cyprinus carpio L., 1758). International Food Research Journal, 17:915-920.

Emir Çoban, Ö. (2013). Effect of Ginger oil on the sensory and chemical changes of fish finger (Sarda sarda, Heckel 1843) during refrigerated storage. International Food Research Journal, 20(4):1575-1578.

Ersoy, B. (2000). Karabalık (Clarias lazera) Köftesinin Buzdolabı Koşullarındaki Raf Ömrü. Su Ürünleri Sempozyumu 22-24 Eylül 2000. Sinop, Türkiye.

Ersoy, B. \& Yılmaz, A.B. (2003). Frozen storage of African catfish (Clarias gariepinus BURCHELL, 1822) mince balls. Turkish Journal of Veterinary and Animal Sciences, 27:827-832. 
Food and Agriculture Organization/World Health Organization (1989). Food Standarts Codex Alimentarius. Standard for quick frozen fish sticks (fish fingers), fish portions and fish fillets-breaded or in batter. Codex Standard, 166:1-10.

Gökoğlu, N. \& Yerlikaya, P. (2009). Bitki Özütleri llave Edilmiş Balık Kroketin Dondurulmuş Depolama Süresince Kalite Değişimlerinin İncelenmesi. 15. Ulusal Su Ürünleri Sempozyumu 2009. Rize, Turkey.

Harrigan, W.F. (1998). Laboratory Methods in Food Microbiology. San Diago: Academic Press.

International Commission on Microbiological Specifications For Foods (1978). Microorganisms in foods (Vol 2). The International Commission on Microbiological Specifications for Foods. Toronto: Canada.

İnanlı, A.G., Çoban, Ö.E., Özpolat, E. \& Dartay, M. (2005). Bıyıkıı balıktan yapılan kroketlerinin soğukta raf ömrünün belirlenmesi (Barbus esocinus, HECKEL, 1843). Su Ürünleri Mühendisleri Derneği Dergisi, 40-44.

İzci, L., Bilgin, Ş. \& Günlü, A. (2011). Production of fish finger from sand smelt (Atherinaboyeri, RISSO 1810) and determination of quality changes. African Journal of Biotechnology, 10(21):4464-4469. doi: $10.5897 / A J B 10.2093$

KIlınç, B. (2007). Microbiological, sensory and color changes of anchovy (Engraulis encrasicholus) patties during refrigerated storage. Journal of Muscle Foods, 20:129-137. doi: 10.1111/j.1745-4573.2009.00139.x

Kietzmann, U., Priebe, K., Rakov, D. \& Reichstein, K. (1969). Seefisch als lebensmittel. Hamburg. Berlin: Paul Parey Verlag.
Kurtcan, Ü. \& Gönül, M. (1987). Gıdaların Duyusal Değerlendirilmesinde Puanlama Metodu. Ege Üniversitesi Mühendislik Fakültesi Dergisi, Seri B, Gıda Mühendisliği, 5(1):137-146.

Lima Dos Santos, C., James, D. \& Teutscher, F. (1981). Guidelines for chilled fish storage experiments. FAO Fisheries Technical Paper (p.210).

Ludorff, W., \& Meyer, V. (1973). Fische und fischerzeugnisse. Hamburg. Berlin: Paul Parey Verlag.

Oehlenschlager, J. (1981). Variation der gehelte an fluchtigen stickstofgehaltigen basen und "TVB-N" in Retbersch. Informationen für die Fischwirtschaft, 53:33-34.

Oxoid, (1982). The Oxoid Manual of Culture Media. Ingredients and Other Laboratory Services. London: Oxoid Ltd.

Patır, B., Öksüztepe, G., Çoban, Ö.E. \& Dikici, A. (2009). Dondurulmuş Karides Etinden Hazırlanan Kroketlerin Raf Ömrü. Fırat Üniversitesi Sağlık Bilimleri Veteriner Dergisi, 23(1):29-37.

Schormüller, J. (1968). Handbuch der lebensmittelchemie (Band III/2). Heidelberg. Berlin: Springer-Verlag.

Sowmya Praneetha, S., Dhanapal, K., Reddy, G.V.S. \& Balasubramanian, A. (2015). Development of fish finger from rohu (labeo rohita) and its quality evaluation during refrigerated storage condition. International Journal of Science, Environment and Technology, 4(6):1457-1468.

Taskaya, L., Cakli, S., Kisla, D. \& KIIInç, B. (2003). Quality changes of fish burger from rainbow trout during refrigerated storage. Journal of Fisheries and Aquatic Sciences, 20:147-154.

Varlık, C., Uğur, M., Gökoğlu, N. \& Gün, H. (1993). Su ürünlerinde kalite kontrol ilke ve yöntemleri. İstanbul, Turkey: Gıda Teknolojisi Derneği. 